\title{
Mites (Arachnida: Acari) collected on rubber trees Hevea brasiliensis (Willd. ex A.Juss.) Müll.Arg. in Santana, Amapá state, Brazil
}

\author{
Deus, EG. ${ }^{a}$, Souza, MSM. ${ }^{b}$, Mineiro, JLC. ${ }^{c}$, Adaime, R. ${ }^{a *}$ and Santos, RS. ${ }^{d}$ \\ ${ }^{a}$ Embrapa Amapá, Rod. JK, Km 5, 2600, CEP 68903-419, Macapá, AP, Brazil

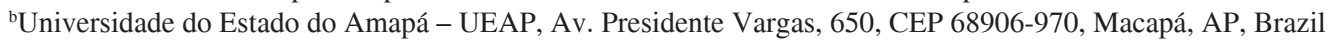 \\ ${ }^{\mathrm{C}}$ Laboratório de Acarologia, Centro Experimental Central do Instituto Biológico, \\ CP 70, CEP 13001-970, Campinas, SP, Brazil \\ ${ }^{\mathrm{d}}$ Embrapa Acre, Rod. BR-364, Km 14, CP 321, CEP 69908-970, Rio Branco, AC, Brazil \\ *e-mail: ricardo.adaime@embrapa.br
}

Received August 9, 2011 - Accepted December 5, 2012 - Distributed November 30, 2012

\begin{abstract}
The purpose of this study was to elaborate a preliminary list of the mite species associated with rubber trees in the municipality of Santana, in the state of Amapá, Brazil. Two collections of rubber tree leaves were conducted on May $2^{\text {nd }}$ and June $5^{\text {th }}, 2010$. Twenty-five plants were sampled at random. Three leaves were collected per plant, from the lower third of the crown. The samples were placed in paper bags, packed in an isothermal box chilled gel-based pulp plant $\left(\right.$ Gelo- $\left.\mathrm{X}^{\circledR}\right)$, and transported to the Entomology Laboratory at Embrapa Amapá, in Macapá. The leaflets were examined under a stereomicroscope, and the mites found on the adaxial and abaxial surfaces of the leaves were collected with a stilet, mounted on microscope slides in Hoyer's medium, and later identified. We collected a total of 1,722 mites of 10 families: Acaridae, Cunaxidae, Eriophyidae, Iolinidae, Phytoseiidae, Stigmaeidae, Tarsonemidae, Tenuipalpidae, Tydeidae, and Winterschmidtiidae, in addition to unidentified species of the suborders Oribatida and Astigmatina. The family Phytoseiidae represented only $2.90 \%$ of specimens collected, but showed the highest species richness ( 5 species). The only representative of Tenuipalpidae was Tenuipalpus heveae Baker, 1945, but 81.13\% of the mites collected in this study belonged to this species.
\end{abstract}

Keywords: Tenuipalpus heveae, Tenuipalpidae, Amazon, Phytoseiidae.

\section{Ácaros (Arachnida: Acari) coletados em seringueira Hevea brasiliensis (Willd. ex A. Juss.) Müll. Arg. em Santana, Estado do Amapá, Brasil}

\begin{abstract}
Resumo
O objetivo deste estudo foi elaborar uma lista preliminar das espécies de ácaros associadas à seringueira, no município de Santana, Estado do Amapá. Foram realizadas duas coletas de folhas de seringueira, nos dias 2 de maio e 5 de junho de 2010. Foram tomadas aleatoriamente 25 plantas, de cada uma das quais foram coletadas três folhas, no terço inferior da copa. As amostras foram acondicionadas em sacos de papel, mantidas em caixa isotérmica refrigerada com gel à base de celulose vegetal $\left(\right.$ Gelo- $\left.\mathrm{X}^{\circledR}\right)$ e transportadas até o Laboratório de Entomologia da Embrapa Amapá, em Macapá. A triagem dos folíolos foi realizada com o auxílio de estereomicroscópio. Os ácaros encontrados nas faces adaxial e abaxial das folhas foram capturados com um estilete, montados em lâminas de microscopia em meio de Hoyer e, posteriormente, identificados. Foram coletados 1.722 ácaros, pertencentes a dez famílias: Acaridae, Cunaxidae, Eriophyidae, Iolinidae, Phytoseiidae, Stigmaeidae, Tarsonemidae, Tenuipalpidae, Tydeidae e Winterschmidtiidae, além de espécies não identificadas das subordens Oribatida e Astigmatina. A família Phytoseiidae representou apenas 2,90\% do total de espécimes coletados, porém apresentou a maior riqueza em espécies (cinco espécies). A família Tenuipalpidae, embora representada apenas por Tenuipalpus heveae Baker, 1945, apresentou o maior número de espécimes capturados $(81,13 \%)$.
\end{abstract}

Palavras-chave: Tenuipalpus heveae, Tenuipalpidae, Amazônia, Phytoseiidae.

\section{Introduction}

The rubber tree, Hevea brasiliensis (Willd. ex A.Juss.) Müll.Arg., is a tropical plant cultivated and used for the extraction of natural rubber (Campelo-Júnior, 2000). Since the 1970's, the total area planted with rubber trees in Brazil has increased considerably (Bernardes, 1992). Approximately 150 thousand hectares are currently planted with rubber trees in Brazil, distributed across several regions of the country (IRSG, 2011). The states of São Paulo, Mato 
Grosso, Bahia, and Espírito Santo are the main producers. The state of São Paulo is the leading producer of natural rubber in the country (Martinez, 2011).

The rubber tree is a plant of major economic relevance. It has therefore received increasing attention in recent decades, given that its usual cultivation over extended areas as a monocrop favours the appearance of pest species. This makes it highly important to study the mite fauna of rubber crops (Feres, 2000; Hernandes and Feres, 2006a). Studies of this nature may lead to the discovery of potential pest species and also their natural enemies, generating data to support the development of integrated pest management programmes specifically designed for rubber tree plantations (Hernandes and Feres, 2006a).

Approximately 118 species of mites of different families have been reported on rubber trees in Brazil (Batista-Filho et al., 2011). Two species of phytophagous mites are considered to be severe pests in the mid-western and southeastern regions of Brazil: Calacarus heveae Feres (Eriophyidae), which has been causing significant leaf drop and a consequent decline in latex yield (Vieira and Gomes, 1999; Feres, 2000; Hernandes and Feres, 2006a); and Tenuipalpus heveae Baker (Tenuipalpidae), which causes bronzing and premature leaf drop, as well as a significant decline in latex production (Pontier et al., 2000; Bellini et al., 2005).

Information on mite diversity is scarce in the state of Amapá. Mineiro et al. (2009) reported the occurrence of mite species on fruit trees and other economically important plants. The authors reported the mite families Ascidae, Phytoseiidae, Cunaxidae, Eriophyidae, Stigmaeidae, Tarsonemidae, Tenuipalpidae, Tetranychidae, and Tydeidae.

In light of the scarcity of scientific information regarding the occurrence of mites on rubber trees in the state of Amapá, it is essential that complementary scientific studies on this group be conducted. The purpose of this work is therefore to enhance the existing scientific knowledge on the mite fauna associated with rubber trees in the southeast portion of the state of Amapá, and provide supporting data for subsequent projects related to this topic.

\section{Material and Methods}

The study was conducted in a rubber tree plantation of a private property known as Retiro São Luiz, located on Km 7 of Rodovia AP-010 highway in the municipality of Santana, in the southeast region of the state of Amapá, Brazil (00 $02^{\circ} \mathrm{S}$ and $\left.51^{\circ} 13^{\prime} \mathrm{W}\right)$. The trees were planted in 1980-1982 over an area of 16 ha.

The planted clones and their respective areas of coverage are: IAN 717 (4 ha), IAN 873 (3 ha), Fx 3810 (4 ha), Fx 3899 ( 3 ha) and Fx 2261 (2 ha). This work was performed on trees of clone Fx 2261, planted in 1982. The choice of the clone was due to the presence of symptoms of mite attack (chlorotic leaves and presence of mites). Also, the plot cultivated with Fx 2261 was the most accessible.

Two collections of rubber tree leaves were carried out, on May $2^{\text {nd }}$ and June $5^{\text {th }}, 2010$. On each sampling date, we selected 25 plants at random and collected three leaves from each of them (comprising a total of 225 leaflets). In the field, the three leaves of each sample were placed in paper bags, packed in an isothermal box chilled gel-based pulp plant $\left(\right.$ Gelo- $\left.\mathrm{X}^{\circledR}\right)$ and transported to the Entomology Laboratory at Embrapa Amapá, in Macapá.

In the laboratory, the leaflets were initially examined under a stereomicroscope. The adaxial and abaxial surfaces of each leaflet were examined and mites found were collected with a stylet and mounted on microscope slides in Hoyer's medium (Moraes and Flechtmann, 2008) for later identification. Voucher specimens were deposited in the mite reference collection of the Instituto Biológico, Campinas, São Paulo, Brazil.

\section{Results and Discussion}

We collected a total of 1,722 mites from 10 families, in addition to unidentified species from the suborders Oribatida and Astigmatina. Mites of the family Phytoseiidae represented only $2.90 \%$ of collected specimens, but presented the highest species richness ( 5 species), followed by Tydeidae (2) and Cunaxidae (2). Other families were represented by a single species each (Table 1 ).

Though represented by a single species (T. heveae), mites of the family Tenuipalpidae were the most abundant; 1,397 tenuipalpids ( $81.13 \%$ of all mites) was found. This is the first record of T. heveae in the state of Amapá. The only tenuipalpid species previously reported in the state is Brevipalpus phoenicis (Geijskes, 1939), on citrus trees (Jordão and Silva, 2006). Tenuipalpus heveae, known as the rubber tree red flat mite, was described from specimens collected in the state of Pará, where it has not been reported as a pest. It is also found in the states of Amazonas, Goiás, Mato Grosso, and São Paulo (Moraes and Flechtmann, 2008). After the year 2000, T. heveae was reported a number of times as a pest of rubber trees (Pontier et al., 2000; Ferla and Moraes, 2002; Hernandes and Feres 2006a, b; Vis et al., 2006; Daud and Feres, 2007). In São Paulo, T. heveae is usually very numerous (Feres et al., 2002; Bellini et al., 2005; Hernandes and Feres, 2006a; Vis et al., 2006). This species inhabits mainly the abaxial surface of leaves and causes bronzing followed by premature leaf drop (Moraes and Flechtmann, 2008). In the plot studied in this work, we observed symptoms of mite attack in several leaves, but it is not possible to say that there was a decrease in the production of latex, because this factor was not evaluated in the present study.

We also collected two other mite families whose feeding habits are not well known: Tydeidae (7.49\% of collected specimens) and Tarsonemidae (0.93\%) (Table 1$)$.

From Tydeidae, we obtained specimens of Lorryia formosa Cooreman, 1958 (58 specimens) and Lorryia sp. (71). From the Tarsonemidae family, we collected Tarsonemus sp. (14 specimens). This is the first record of this genus in the state of Amapá. We collected three specimens of Czenspinskia sp., family Winterschmidtiidae. Unidentified 
mites of this genus have been reported on rubber trees in São Paulo (Hernandes and Feres, 2006b).

Only one (unidentified) specimen of Eriophyidae was collected. Calacarus heveae Feres, 1992, an important pest species in São Paulo state, was not observed during this study. In the Brazilian Amazon, there is no report of extensive infestation by $C$. heveae (Feres, 2001). To confirm the absence of the species in Amapá, further surveys in rubber tree plantations are recommended.

Families of predatory mites were also represented in our collections: Phytoseiidae, Stigmaeidae, and Cunaxidae. Phytoseiidae was represented by Typhlodromips sp.1, Typhlodromips sp.2, Galendromus sp., Amblyseius sp., and Euseius sp. Stigmaeidae was represented by Agistemus sp. From the family Cunaxidae, we obtained specimens of Armascirus and Pulaeus.

We observed that several specimens of T. heveae mounted on slides were infected by the fungus Hirsutella sp., suggesting that the fungus is probably involved in the biological control of this mite species. In Itiquira, in the state of Mato Grosso, Tanzini et al. (2000) and Demite and Feres (2008) reported infestation by Hirsutella thompsonii Fisher on the mites Phyllocoptruta seringueirae Feres, 1998, C. heveae, and T. heveae. In the state of São Paulo $H$. thompsonii, has been observed infesting $C$. heveae mites collected on rubber trees (van der Geest et al., 2002; Bellini et al., 2005). In this work, one specimen of the predatory mite Agistemus sp. (Stigmaeidae) was also infected by Hirsutella sp.

Acknowledgements - To the Brazilian Council for Scientific and Technological Development - CNPq for the Human Resource Stability Fellowship granted to the first author. To Mr. Aluísio Aragão de Souza and Mr. Clodoaldo dos Santos Juarez, respectively, for allowing access to the study site and for providing data required for the development of this work.

Table 1. Mite species collected on rubber trees in Santana, Amapá, 2010.

\begin{tabular}{|c|c|c|c|}
\hline \multirow{2}{*}{ Rate } & \multirow{2}{*}{ Species } & \multicolumn{2}{|c|}{ Specimens } \\
\hline & & Number & $\%$ \\
\hline \multirow[t]{2}{*}{ Tenuipalpidae } & & 1,397 & 81.13 \\
\hline & Tenuipalpus heveae* & 1,397 & 81.13 \\
\hline \multirow[t]{3}{*}{ Tydeidae } & & 129 & 7.49 \\
\hline & Lorryia formosa & 58 & 3.37 \\
\hline & Lorryia sp. & 71 & 4.12 \\
\hline \multirow[t]{2}{*}{ Stigmaeidae } & & 59 & 3.42 \\
\hline & Agistemus sp.** & 59 & 3.42 \\
\hline \multirow[t]{7}{*}{ Phytoseiidae } & & 50 & 2.90 \\
\hline & Typhlodromips sp.1 & 10 & 0.58 \\
\hline & Typhlodromips sp.2 & 5 & 0.29 \\
\hline & Galendromus sp. & 4 & 0.23 \\
\hline & Amblyseius sp. & 1 & 0.06 \\
\hline & Euseius sp. & 7 & 0.41 \\
\hline & Immatures (nymphs) & 23 & 1.33 \\
\hline \multirow[t]{2}{*}{ Winterschmidtiidae } & & 3 & 0.17 \\
\hline & Czenspinskia sp. & 3 & 0.17 \\
\hline Oribatida & n.i. $* * *$ & 42 & 2.44 \\
\hline Eriophyidae & n.i. $* * *$ & 1 & 0.06 \\
\hline \multirow[t]{4}{*}{ Cunaxidae } & & 7 & 0.41 \\
\hline & Pulaeus sp. & 1 & 0.06 \\
\hline & Armascirus sp. & 1 & 0.06 \\
\hline & Immatures (nymphs) & 5 & 0.29 \\
\hline \multirow[t]{3}{*}{ Tarsonemidae } & & 16 & 0.93 \\
\hline & Tarsonemus sp. & 14 & 0.81 \\
\hline & Immatures (nymphs) & 2 & 0.12 \\
\hline Astigmatina & n.i. $* * *$ & 1 & 0.06 \\
\hline Iolinidae & n.i. $* * *$ & 7 & 0.41 \\
\hline Acaridae & n.i.**** & 10 & 0.58 \\
\hline Total & & 1,722 & 100.00 \\
\hline
\end{tabular}

*The total includes 242 nymphs; ** The total includes 8 nymphs; ***n.i. = not identified. 


\section{References}

BATISTA-FILHO, A., RAGA, A., BUENO, CJ., FURTADO, EL., ALMEIDA, JEM., MINEIRO, JLC., LEITE, LG. and SANTOS, RS., 2011. Doenças e Pragas em Seringueiras. São Paulo: Instituto Biológico. 79 p. (Boletim Técnico, no. 25).

BELLINI, MR., MORAES, GJ. and FERES, RJF., 2005. Ácaros (Acari) de dois sistemas de cultivo da seringueira no noroeste do estado de São Paulo. Neotropical Entomology, vol. 34, no. 3, p. 475-484. http://dx.doi.org/10.1590/S1519-566X2005000300017

BERNARDES, MS., 1992. Cultura da seringueira no Estado de São Paulo e perspectivas para a produção de mudas. In MEDRADO, MJS., BERNARDES, MS., COSTA, JD. and MARTINS, AN. (Eds.). Formação de mudas e plantio de seringueira. Piracicaba: ESALQ. p. 1-8.

CAMPELO-JÚNIOR, JH., 2000. Estimativa da transpiração em seringueira. Revista de Agrometeorologia, vol. 8, no. 1, p. 35-42.

DAUD, RD. and FERES, RJF., 2007. Dinâmica populacional de ácaros fitófagos (Acari, Eriophyidae, Tenuipalpidae) em seis clones de seringueira no sul do Estado de Mato Grosso. Revista Brasileira de Entomologia, vol. 51, p. 377-381. http://dx.doi. org/10.1590/S0085-56262007000300016

DEMITE, PR. and FERES, RJF., 2008. Seasonality of pathogenic fungi in mites of rubber tree plantations adjacent to fragments of Cerrado. Brazilian Journal of Biology, vol. 68, no. 3, p. 535-538. http://dx.doi.org/10.1590/S1519-69842008000300010

FERES, RJF., 2000. Levantamento e observações naturalísticas da acarofauna (Acari: Arachnida) de seringueiras cultivadas (Hevea spp., Euphorbiaceae) no Brasil. Revista Brasileira de Zoologia, vol. 17, n. 1, p. 157-173. http://dx.doi.org/10.1590/ S0101-81752000000100011

-, 2001. Primeiro registro de ácaros eriofí́deos (Acari, Eriophyidae) em seringueiras (Hevea brasiliensis Muell. Arg., Euphorbiaceae) da Floresta Amazônica, Brasil. Revista Brasileira de Zoologia, vol. 18, p. 343-345. http://dx.doi.org/10.1590/S0101-81752001000500030

FERES, RJF., ROSSA-FERES, DC., DAUD, RD. and SANTOS, RS., 2002. Diversidade de ácaros (Acari, Arachnida) em seringueiras (Hevea brasiliensis Muell. Arg., Euphorbiaceae) na região noroeste do Estado de São Paulo, Brasil. Revista Brasileira de Zoologia, vol. 19, p. 137-144. http://dx.doi.org/10.1590/S010181752002000100011

FERLA, NJ. and MORAES, GJ., 2002. Ácaros (Arachnida, Acari) da seringueira (Hevea brasiliensis Muell. Arg.) no Estado do Mato Grosso, Brasil. Revista Brasileira de Zoologia vol. 19, p. 867-888. http://dx.doi.org/10.1590/S0101-81752002000300025
HERNANDES, FA. and FERES, RJF., 2006a. Diversidade e sazonalidade de ácaros (Acari) em seringal (Hevea brasiliensis, Muell. Arg.) no noroeste do estado de São Paulo. Neotropical Entomology, vol. 35, p. 523-535. http://dx.doi.org/10.1590/ S1519-566X2006000400016

-, 2006b. Review about mites (Acari) of rubber trees (Hevea spp., Euphobiaceae) in Brazil. Biota Neotropica, vol. 6, p. 1-24. http:// dx.doi.org/10.1590/S1676-06032006000100005

International Rubber Study Group - IRSG, 2011. Banco de Dados 2008. Available from: <http://www.rubberstudy.com> Acess in: 11 out. 2011.

JORDÃO, AL. and SILVA, RA., 2006. Guia de pragas agrícolas para o manejo integrado no Estado do Amapá. Ribeirão Preto: Holos. 183 p.

MARTINEZ, AA., 2011. Borracha: São Paulo é o maior produtor nacional. Available from: <http://www.infobibos.com/artigos/ borracha/index.htm>. Acess in: 11 out. 2011.

MINEIRO, JLC., SILVA, WR. and SILVA, RA., 2009. Ácaros em fruteiras e outras plantas no Estado de Amapá. Biota Neotropica, vol. 9, no. 2, p. 103-106. http://dx.doi.org/10.1590/S167606032009000200009

MORAES, GJ. and FLECHTMANN, CHW., 2008. Manual de Acarologia Agrícola: acarologia básica e ácaros de plantas cultivadas no Brasil. Ribeirão Preto: Holos. 308 p.

PONTIER, KJB., MORAES, GJ. and KREITER, S., 2000. Biology of Tenuipalpus heveae (Acari, Tenuipalpidae) on rubber tree leaves. Acarologia, vol. 41, p. 423-427.

TANZINI, MR., ALVES, SB., TAMAI, MA., MORAES, GJ. and FERLA, NJ., 2000. An epizootic of Calacarus heveae (Acari: Eriophyidae) caused by Hirsutella thompsonii on rubber trees. Experimental and Applied Acarology, vol. 24, n. 2, p. 141-144. http://dx.doi.org/10.1023/A:1006303419987

VAN DER GEEST, LPS., MORAES, GJ., NAVIA, D. and TANZINI, MR., 2002. New records of pathogenic fungi in mites (Arachnida: Acari) from Brazil. Neotropical Entomology, vol. 31, no. 3, p. 493-495. http://dx.doi.org/10.1590/S1519$566 \times 2002000300025$

VIEIRA, MR. and GOMES, EC., 1999. Sintomas, desfolhamento e controle de Calacarus heveae Feres, 1992 (Acari: Eriophyidae) em seringueira (Hevea brasiliensis Müell. Arg.). Cultura Agronômica, vol. 8 , no. 1 , p. 53-71.

VIS, RMJ., MORAES, GJ. and BELLINI, MR., 2006. Mites (Acari) of rubber trees (Hevea brasiliensis Muell. Arg., Euphorbiaceae) in Piracicaba, State of São Paulo, Brazil. Neotropical Entomology, vol. 35, p. 112-120. http://dx.doi.org/10.1590/ S1519-566X2006000100015 